\title{
Upaya Meningkatkan Prestasi Belajar Siswa Dengan Menggunakan Media Audio Visual di Sekolah Dasar Negeri 5 Bengkulu Tengah
}

\author{
Nuraini $^{1}$, Anwardani ${ }^{2}$ dan Surya Evi Idayanti ${ }^{3}$ \\ ${ }_{1,2,3}$ Sekolah Dasar Negeri Nomor 5 Kabupaten Bengkulu Tengah \\ Jl. Raya Bukit Sunur, Taba Lagan Kec. Talang Empat Kabupaten Bengkulu Tengah \\ Email : *Nuraini1767@gmail.com
}

\begin{abstract}
ABSTRAK
Masalah penelitian tindakan kelas ini adalah rendahnya prestasi belajara siswa dalam beberapa mata pelajaran Seni Budaya dan Prakarya pada siswa Sekolah Dasar Negeri 5 Bengkulu Tengah. Tahun Pelajaran 2018/2019. Namun tujuan penelitian ini adalah meningkatkan prestasi belajar siswa dalam pembelajaran Seni Budaya dan Prakarya. Hasil penelitian ini dapat bermanfaat langsung bagi sekolah, yaitu meningkatkan kualitas pembelajaran Senibudaya dan Prakarya, disamping itu bermanfaat bagi guru dan siswa. Penelitian ini dilaksanakan dalam dua siklus, dimana aktivitas setiap siklusnya meliputi perencanaan, tindakan, observasi, evaluasi, dan refleksi. Subjek penelitian adalah siswa SD Negeri 5 Bengkulu Tengah sebanyak satu kelas. Metode pemecahan masalah yang digunakan adalah penerapkan pembelajaran dengan menggunakan media audio-visual pada pelajaran Seni Budaya dan Prakarya, materi peristiwa sekitar proklamasi. Instrumen penelitian menggunakan lembar tes siswa. Pelaksanaan penelitian secara kolaboratif dengan melibatkan empat orang guru Senibudaya dan Prakarya. Seorang guru Senibudaya dan Prakarya. bertindak sebagai pelaksana tindakan dan tiga orang lagi bertindak sebagai pengamat proses pembelajaran yang berlangsung. Hasil penelitian ini menunjukan peningkatan prestasi belajar siswa. Siklus I dengan rata-rata skor prestasi belajar siswa 59,23 dengan kriteria ketuntasan 61,54\%. Siklus II dengan rata-rata skor prestasi belajar siswa 69,61 dengan kriteria ketuntasan 89,74. Dengan demikian menggunakan ini berhasil meningkatkan prestasi siswa dalam pelajaran Seni Budaya dan Prakarya.
\end{abstract}

Kata kunci : media audio-visual dan prestasi belajar

\section{PENDAHULUAN}

Keberhasilan dalam pembelajaran dipengaruhi oleh faktor-faktor yang terlibat dalam semua kegiatan belajar mengajar. Diantara faktorfaktor tersebut adalah siswa, guru, kebiajakan pemerintah dalam membuat kurikulum, serta dalam proses belajar seperti metoda, sarana dan prasarana (media pembelajaran), model, dan pendekatan belajar yang digunakan. Kondisi riil dalam pelaksanaannya latihan yang diberikan tidak sepenuhnya dapat meningkatkan kemampuan siswa dalam menerapkan konsep. Rendahnya mutu pembelajaran dapat diartikan kurang efektifnya proses pembelajaran. Penyebabnya dapat berasal dari siswa, guru maupun sarana dan prasarana yang ada, minat dan motivasi siswa yang rendah, kinerja guru yang rendah, serta sarana dan prasarana yang kurang memadai akan menyebabkan pembelajaran menjadi kurang efektif. Saat sekarang ini sistem pembelajaran harus sesuai dengan kurikulum yang digunakan. Jadi pendidikan tidak hanya ditekankan pada aspek kognitif saja tetapi juga afektif dan psikomotorik.

Permasalahan yang dialami dalam mata pelajaran Seni Budaya dan Prakarya meliputi faktor internal dan faktor eksternal. Faktor internal yang dialamai oleh siswa meliputi hal-hal seperti; sikap terhadap belajar, motivasi belajar, konsentrasi belajar, kemampuan mengolah bahan belajar, kemampuan menyimpan perolehan hasil belajar, kemampuan menggali hasil belajar yang tersimpan, kemampuan berprestasi atau unjuk hasil belajar, rasa percaya diri siswa, intelegensi dan keberhasilan belajar, kebiasaan belajar dan cita-cita siswa. Faktorfaktor internal ini akan menjadi masalah sejauh siswa tidak dapat menghasilkan tindak belajar yang menghasilkan hasil belajar yang baik. (Dimyati \& Mudjiono, 2002).

Faktor eksternal meliputi hal-hal sebagai berikut; guru sebagai pembimbing belajar, prasarana dan sarana pembelajaran, kebijakan penilaian, lingkungan siswa di sekolah, dan kurikulum sekolah. Dari sisi guru sebagai pembelajar maka peranan guru dalam mengatasi masalah-masalah eksternal belajar merupakan prasyarat terlaksanannya siswa dapat belajar.(Dimyati \& Mudjiono, 2002)

Media pembelajaran sebagai salah satu sumber belajar ikut membantu guru memperkaya wawasan anak didik. Aneka macam bentuk dan jenis media pendidikan yang digunakan oleh guru menjadi sumber ilmu pengetahuan bagi anak didik. Dalam menerangkan suatu benda, guru dapat membawa bendanya secara langsung ke hadapan anak didik di kelas. Dengan menghadirkan bendanya seiring dengan penjelasan mengenai benda itu, maka benda itu dijadikan sebagai sumber belajar.

Kalau dalam pendidikan di masa lalu, guru merupakan satu-satunya sumber belajar bagi anak didik. Sehingga kegiatan pendidikan cenderung masih tradisional. Perangkat teknologi penyebarannya masih sangat terbatas dan belum memasuki dunia pendidikan. Tetapi lain halnya 
sekarang, perangkat teknologi sudah ada dimanamana. Pertumbuhan dan perkembangannya hampirhampir terkendali, sehingga wabahnya pun menyusup ke dalam dunia pendidikan. Di sekolahsekolah kini, terutama di kota-kota besar, teknologi dalam berbagai bentuk dan jenisnya sudah dipergunakan untuk mencapai tujuan. Ternyata teknologi, yang disepakati sebagai media itu, tidak hanya sebagai alat bantu, tetapi juga sebagai sumber belajar dalam proses belajar mengajar. Media sebagai sumber belajar diakui sebagai alat bantu auditif, visual, dan audiovisual. Penggunaan ketiga jenis sumber belajar ini tidak sembarangan, tetapi harus disesuaikan dengan perumusan tujuan instruksional, dan tentu saja dengan kompetensi guru itu sendiri, dan sebagainya.

Anjuran agar menggunakan media dalam pengajaran terkadang sukar dilaksanakan, disebabkan dana yang terbatas untuk membelinya. Menyadari akan hal itu, disarankan kembali agar tidak memaksakan diri untuk membelinya, tetapi cukup membuat media pendidikan yang sederhana selama menunjang tercapainya tujuan pengajaran. Cukup banyak bahan mentah untuk keperluan pembuatan media pendidikan dan dengan pemakaian keterampilan yang memadai untuk tercapainya tujuan. Media adalah segala sesuatu yang dapat digunakan untuk menyalurkan pesan dari pengirim ke penerima sehingga dapat merangsang pikiran, perasaan, perhatian, dan minat serta perhatian siswa sedemikian rupa sehingga proses belajar mengajar terjadi.

Dengan demikian, penggunaan media pembelajaran yang bisa melibatkan lebih dari satu indra akan berpengaruh terhadap kualitas informasi yang diterima, dan semakin efektifnya dalam proses mengingat terhadap informasi yang sudah diterima.

\section{METODOLOGI PENELITIAN}

\subsection{Waktu dan Tempat Penelitian}

Peneilitian ini dilaksanakan di SD Negeri 5 Bengkulu Tengah. Subyek penelitian, yaitu siswa di kelas VI berjumlah 39 siswa yang terlibat dalam proses pembelajaran Seni Budaya dan Prakarya, dengan siswa yang terdiri dari beragam karakter, serta kondisi social ekonomi yang heterogen; dan

\subsection{Subyek Penelitian}

Subyek dalam kegiatan penelitian ini adalah siswa kelas VI.A sebanyak 39 orang, terdiri dari putra sebanyak 23 orang dan putri sebanyak 16 orang.

\subsection{Instrumen Penelitian}

Instrumen dalam penelitian tindakan kelas adalah peneliti sendiri, sebagai sole instrument (HopsKins, 1993), sedangkan teknik pengumpulan datanya ialah tes hasil belajar siswa, khususnya mengenai penguasaan terhadap materi atau pokok bahasan yang dibelajarkan dengan menggunakan model pemanfaatan media audio visual sebagai sumber pembelajaran Seni Budaya dan Prakarya.

\subsection{Pengolahan Data}

Dalam penelitian tindakan, pada dasarnya proses analisis data sudah dilakukan sebelum program tindakan tersebut dilaksanakan, sehingga analisis data berlangsung dari awal sampai akhir pelaksanaan program tindakan itu (Suwarsih, 1994; McNiff, 1992). Dalam penelitian ini, data penelitian program tindakan sesuai dengan karakteristik focus permasalahan dan tujuan penelitian (Hopskins, 1993; Kemmis, 1983).Data penelitian akan dianalisis secara kualitatif dan kuantitatif. Analisis kualitatif dipergunakan untuk menganalisis data yang memperlibatkan dinamika proses, dengan memberikan pemaknaan secara kontekstual dan mendalam sesuai dengan permasalahan penelitian, yaitu data tentang unjuk kerja guru, aktivitas belajar siswa, pola pembelajaran, pendapat siswa dan guru tentang upaya peningkatan prestasi belajar siswa dengan menggunakan Media Audio Visual pada pelajaran Senibudaya dan Prakarya, serta kemungkinan aplikasi model ini bagi pembelajaran materi atau mata pelajaran lainnya. Adapun analisis kuantitatif mencakup deskripsi berbagai dinamika kemajuan kualitas hasil belajar siswa dalam hubungannya dengan penguasaan konsep/materi pokok bahasan yang diajarkan oleh guru. Untuk itu dipergunakan analisis statistic deskriptif.

\section{HASIL PENELITIAN}

Untuk mengetahui kondisi awal proses pembelajaran Senibudaya dan Prakarya, maka penelitian ini melakukan pengamatan ke kelas. Adapun pengamatan difokuskan pada kegiatan guru dalam membuka pelajaran, penyampaian materi, metode yang digunakan. media dan sumber belajar, aktivitas siswa, serta kegiatan menutup pelajaran dan evaluasi.

Observasi pertama dilakukan pada hari Senin, tanggal 14 Maret 2019. Pada kegiatan awal pembelajaran, setelah guru mengabsen siswa langsung menjelaskan bagaimana proses Membuat karya tangan Sederhana,. Metode pembelajaran yang dipergunakan adalah metode ceramah, dengan sekali-kali bertanya kepada siswa, dan dijawab oleh siswa secara serempak. Guru tidak menggunakan media pembelajaran lain selain spidol dan papan tulis, sedangkan sumber pembelajaran yang dipergunakan guru yaitu buku Seni Budaya dan Praakarya. Aktivitas siswa sangat kurang, mereka hanya mendengarkan ceramah dari guru dan sekalikali menjawab pertanyaan guru secara serempak. Selanjutnya dalam mengakhiri pelajaran guru hanya menyampaikan salam, tanpa memberikan kesimpulan ataupun penguatan-penguatan.

Observasi kedua dilaksanakan pada tanggal 21 Maret 2019. Dengan pokok bahasan "Membuat karya tangan Sederhana".

Pada observasi kedua kegiatan pembelajaran hampir sama dengan kegiatan pertama. Dalam membuka pelajaran setelah mengucapkan salam guru langsung menanyakan apakah ada siswa yang tidak masuk. Kemudian guru menjelaskan materi lanjutan minggu sebelumnya.Metode yang digunakan adalah metode 
ceramah dengan sekali-kali bertanya pada siswa secara klasikal. Guru juga tidak memanfaatkan media pembelajaran. Sumber belajar juga sama yaitu buku Seni Budaya dan Prakarya. Setelah selesai menjelaskan, guru kemudian bertanya kepada siswa apakah ada yang ditanyakan. Namun tidak mendapat respon dari siswa, karena aktivitas siswa juga tidak jauh berbeda seperti aktivitas pada pembelajaran sebelumnya. Karena tidak ada yang bertanya kemudian guru menyuruh siswa mengerjalan soal dalam LKS dari penerbit. Siswa baru terlihat aktif mengerjakan soal di LKS dari penerbit. Bagi yang telah selesai mengerjakan soal-soal, kemudian hasil kerjanya dikumpulkan ke depan, kemudian guru langsung memeriksa dan segera dikembalikan kepada siswa. Selanjutnya guru mengakhiri kegiatan pembelajaran dengan mengingatkan supaya belajar dengan baik karena tinggal beberapa hari lagi akan ujian semester.

Observasi ke tiga dilaksanakan pada tanggal 24 Maret 2019 Pada observasi ke tiga proses pembelajaran juga masih didominasi oleh guru. Kegiatan pembelajaran diawali dengan mengucap salam dan dilanjutkan dengan menanyakan siswa yang tidak masuk. Selanjutnya guru memberi penjelasan tentang topik pada hari itu dan sekali-kali mengajukan pertanyaan kepada siswa secara klasikal. Selesai memberikan penjelasan guru kemudian meminta siswa untuk mengerjakan soal latihan yang ada di LKS dari penerbit. Bagi yang telah selesai kemudian dikumpulkan dan langsung diperiksa oleh guru. Selesai diperiksa buku LKS dari penerbit kemudian dibagikan kepada siswa. Kemudian guru mengakhiri dengan mengucap salam tanpa memberikan penguatan, kesimpulan atau menjelaskan kesalahan yang dibuat siswa dalam latihan mereka.

\section{Analisis, Refleksi dan Rencana Pembelajaran dengan Menggunakan Media Audio Visual}

Berdasarkan hasil temuan awal pada pembelajaran Seni Budaya dan Prakarya di kelas, menunjukkan bahwa pembelajaran Seni Budaya dan Prakarya belum terlaksana dengan baik. Hal ini nampak dari kegiatan pembelajaran yang masih didominasi oleh guru. Guru terpaku pada materi yang disajikan yaitu yang ada pada buku pegangan sementara siswa hanya memiliki LKS dari penerbit sebagai buku pegangan, tidak ditunjang oleh media pembelajaran, gaya mengajar sangat monoton, guru menggunakan metode ceramah dan sekali-kali bertanya kepada seluruh siswa dan siswa menjawab dengan serempak. Di samping itu kondisi siswa cenderung pasif, bahkan terlihat ada beberapa siswa yang terus menerus menguap dan menampakkan kejenuhan dalam belajar. Sering pula terlihat siswa yang duduk di belakang malah asyik mengobrol dengan teman sebangkunya. Secara umum siswa menunjukkan kurang bergairah dan kurang motivasi belajar.

Kegiatan pembelajaran setiap pertemuan berlangsung selama 80 menit. Kegiatan inti berlangsung selama kurang lebih 60 menit, dilanjutkan dengan tes di mana guru mendiktekan soal yang kemudian dikerjakan oleh para siswa selama kurang lebih 15 menit (untuk pertemuan ke dua dan ke tiga). Hasil dari evaluasi siswa dikumpulkan kepada guru. Pada orientasi kedua hasil pekerjaan siswa hanya dikumpulkan sedangkan pada orientasi ketiga hasil kerja siswa langsung diperiksa dan dibagikan.

Berdasarkan hasil temuan lapangan, maka pada analisis dan refleksi awal menunjukkan bahwa kondisi yang demikian menuntut guru agar meningkatkan kinerjanya dan melatih keterampilannya supaya ia mampu menyampaikan pelajaran IPS dengan baik, mampu membangkitkan semangat dan kegairahan dalam belajar, serta tertuntut untuk kreatif dan inovatif dalam belajar. Siswa diharapkan tidak hanya menunggu materi yang disampaikan guru, melainkan pula aktif dalam membaca dan menemukan materi yang dipelajarinya. Penerapan pembelajaran dengan menggunakan media audio visual dapat digunakan sebagai salah satu alternatif perbaikan proses pembelajaran pendidikan Seni Budaya dan Prakarya. Terlebih lagi dalam upaya membangkitkan semangat belajar siswa.

Beberapa hal yang dapat memberikan peluang dan dimungkinkannya untuk pengembangan pembelajaran dengan menerapkan media audio visual, yaitu : adanya dukungan dari kepala sekolah dari hasil wawancara, potensi dan keinginan siswa dari hasil wawancara dan pengamatan di kelas, serta dukungan dari guru Seni Budaya dan Prakarya yang ingin belajar menerapkan pembelajaran dalam bentuk permainan.

Untuk itu selanjutnya peneliti melakukan sosialisasi tentang penerapan pembelajaran dengan menerapkan media audio visual.

\section{Sosialisasi Pembelajaran dengan Menggunakan Media Audio Visual \\ Sebelum pelaksanaan tindakan kelas} dimulai terlebih dahulu peneliti memberikan pemahaman yang mendalam kepada guru tentang pembelajaran dengan menerapkan media audio visual. Adapun materi yang dibahas, meliputi :

a. Pengertian media audio visual.

b. Pembelajaran dengan menggunakan media audio visual.

c. Keunggulan pembelajaran dengan menggunakan media audio visual.

d. Langkah-langkan penerapan pembelajaran dengan menggunakan media audio visual dalam pembelajaran Seni Budaya dan Prakarya, yang meliputi tahap perencanaan, pelaksanaan, dan evaluasi.

Setelah dilakukan sosialisasi tentang pembelajaran dengan menggunakan media audio visual, tiga pertanyaan diajukan oleh guru

a. Apakah penerapan model pembelajaran ini nantinya tidak mengganggu proses pembelajaran?

b. Apakah nantinya target materi Seni Budaya dan Prakarya, bisa tercapai sesuai dengan waktu 
yang ada?

c. Apakah dalam merancang maupun dalam menerapkan model ini guru akan bekerja bersama-sama dengan peneliti?

Setelah dilakukan analisis dan refleksi terhadap gambaran awal pembelajaran Seni Budaya dan Prakarya di kelas, serta hasil diskusi dengan guru, maka diperoleh suatu kesepakatan sebagai berikut:

a. Pelaksanaan tindakan mengikuti jadwal pelajaran Seni Budaya dan Prakarya.

b. Pelaksanaan tindakan adalah upaya untuk meningkatkan kualitas pembelajaran Seni Budaya dan Prakarya, melalui pembelajaran dengan menggunakan media audio visual.

c. Pelaksanaan tindakan akan dilakukan beberapa kali sampai tujuan yang diharapkan tercapai.

d. Adanya kerjasama antara peneliti dan guru yang berperan sebagai mitra di dalam penelitian tindakan kelas dalam membuat rancangan pembelajaran serta untuk mencapai keberhasilan pelaksanaan tindakan.

e. Guru juga tidak keberatan bahwa peneliti menggunakan alat bantu yang berupa media audio visual maupun kamera foto.

f. Peneliti bersama guru membuat perencanaan pembelajaran. Untuk kegiatan pelaksanaan pembelajaran tindakan pertama akan dilaksanakan pada tanggal 21 Februari 2019. Materi yang disampaikan pada pelaksanaan tindakan adalah standar kompetensi

g. Proses pembelajaran difokuskan kepada pemberdayaan siswa agar tercipta suasana kelas yang aktif dan kreatif.

\subsection{Pelaksanaan Penelitian}

\section{Siklus 1}

\section{a. Tahap Perencanaan}

Pembelajaran pertama direncanakan menyampaikan standar kompetensi "Membuat Kerajina tangan Sederhana" Pembelajaran ini akan dilaksanakan dengan menggunakan media audio visual. Penyampaian pelajaran tersebut direncanakan diawali dengan mengingatkan siswa terhadap berbagai hal yang terkait dengan berbagai kegiatan seni budaya yang biasa dialami oleh siswa.

Upaya untuk lebih fokus dalam mengamati setiap aktivitas siswa, pembelajaran akan dilaksanakan dalam bentuk kelompok-kelompok kecil yang akan diamati oleh beberapa orang observer. Satu orang observer hanya mengamati secara seksama dua atai tiga kelompok. Sementara itu media audio visual yang akan digunakan telah disiapkan oleh guru yang dibuat dalam bentuk tayangan power point.

Proses pembelajaran di rencanakan untuk kurang lebih 20 menit siswa menyimak materi yang ditayangkan melalui tayangan power point Selanjutnya siswa berdiskusi mengenai materi yang dipelajarinya dan selanjutnya akan dikomunikasikan dan ditarik kesimpulan dari materi yang telah dipelajarinya.

\section{b. Tahap Pelaksanaan}

Proses pembelajaran pada siklus pertama, dilakukan pada hari Senin tanggal 4 Maret 2019. Guru memulai pembelajaran dengan mengucapkan salam, dilanjutkan dengan mengabsen siswa. Kemudian memberitahukan siswa bahwa kegiatan pembelajaran Seni Budaya dan Prakarya, pada hari ini akan membahas standar kompetensi "Membuat Kerajinan tangan Sedrehana" dan yang menjadi materi pokoknya adalah. Di samping itu guru menginformasikan pula bahwa materi tersebut akan disampaikan dengan menggunakan media audio visual.

Kegiatan selanjutnya guru menginstruksikan siswa untuk berkelompok. Sementara itu jumlah dan nama-nama angggota kelompok sudah ditentukan, dengan tujuan agar setiap kelompok seimbang. siswa berkelompok dengan cara membalikkan meja berhadap-hadapan. Dalam proses pembentukan kelompok ini masih ada siswa yang kurang mengikuti atau tidak sesegera mungkin bergabung dengan kelompoknya. Akibatnya proses penyusunan kelompok memerlukan waktu yang cukup lama.

Selanjutnya, guru menginstruksikan siswa untuk menyimak tayangan power point yang telah dipersiapkan. Guru menginstruksikan pula pada siswa untuk menyediakan alat tulis agar siswa mampu menuliskan berbagai informasi yang disimaknya. Setelah seluruh peralatan siap, guru memulai menayangkan power point sementara siswa mulai melakukan kegiatan menyimak informasi yang disampaikan. Siswa nampak menyimak isi atau pesan yang disampaikan dari slide-slide power point yang disampaikan. Setelah selesai siswa menyimak, langkah selanjutnya guru menginstruksikan siswa untuk mengingat-ingat kembali seluruh materi yang ditayangkan dalam power point.

Setelah selesai proses menyimak, selanjutnya guru mempersilakan siswa untuk berdiskusi sebentar terkait dengan penyampaian materi melalui tayangan slide-slide power point. Selanjutnya guru memberikan aeberapa pertanyaan yang berhubungan dengan materi yang disampaikan melalu penayangan power point tadi.

Sebelum pembelajaran berakhir, guru memberikan tes untuk diisi oleh siswa. Setelah diisi, guru menginstruksikan siswa untuk mengumpulkan kembali tes tersebut. Tes ini berisi beberapa pertanyaan tentang materi yang telah disampaikan. Hal ini dimaksudkan untuk mngukur sampai seberapa besar kemampuan siswa menangkap materi yang dipelajari melalui tayangan power point.

\section{c. Hasil Pembelajaran}

Setelah semua hasil jawaban siswa dianalisis dengan merujuk pada kriteria penilaian yang telah ditetapkan, dapat disimpulkan bahwa rata-rata siswa telah dapat menuliskan hal-hal esensial dari materi yang disimaknya. Hasil penilaian terhadap kemampuan siswa dalam 
memahami materi setelah tayangan media power point pada siklus I ini dapat deskripsikan pada tabulasi berikut ini.

Hasil kemampuan penguasaan materi siswa yang ditunjukkan dengan kemampuan menjawab pertanyaan yang berhubungan dengan materi yang telah diinformasikan seperti pada tabulasi di atas, tampak bahwa secara umum kemampuan siswa dalam penguasaan materi baru berada pada kondisi yang cukup baik dengan pencapaian rata-rata 59,23 Nilai tertinggi yang dicapai siswa pada siklus I ini adalah 75 dan nilai terendah yang diperoleh siswa hanya 40. Sementara itu diamati dari ketuntasan belajar siswa pada siklus I ini baru mencapai ketuntasan belajar sebesar $61,54 \%$. Ketuntasan tersebut menunjukkan pembelajaran belum tuntas.

\section{d. Hasil Observasi Siswa}

Berdasarkan data observasi, guru telah menyampaikan penjelasan materi dengan jelas dan relevan dengan fokus pembelajaran siklus I. Guru juga sudah berhasil mengarahkan dan membimbing siswa untuk menuangkan hal-hal penting yang terdapat dalam materi yang disimaknya.

Proses pembelajaran pada siklus I umumnya cukup baik, pada umumnya siswa memperhatikan isi materi dan serius dalam mengerjakan tugas, serta sebagian kecil siswa yang melakukan kegiatan yang tidak sesuai dengan KBM, seperti mengobrol, tidak memperhatikan atau main-main dalam belajar. Segi keaktifan yang diharapkan dari siswa belum dapat terealisasi dengan baik. Dapat dilihatnya dari hanya dua orang siswa yang mau tampil di depan kelas, bertanya ataupun mengemukakan pendapat Hal itu, disebabkan pertemuan ini adalah pertemuan pertama yang menyebabkan siswa terlihat malu dan ragu untuk aktif di kelas.

Hasil catatan lapangan pembelajaran tindakan pertama dapat dilihat pada tabel di bawah ini.

Tabel 4.3 Catatan Lapangan Pembelajaran Siklus I

\section{Catatan Lapangan Pembelajaran Siklus I}

1) Siswa masih merasa malu untuk menjawab atau memberikan pertanyaan.

1) Masih sedikitnya siswa yang mau tampil di depan kelas untuk membacakan hasil pekerjaannya.

2) Suasana hening saat menyimak materi yang dilakukan oleh temannya sebagai stimulus motivasi keaktifan siswa.

3) Siswa terlihat antusias saat guru menginstruksikan untuk belajar dengan menggunakan media audio visual power point.

4) Siswa dengan saksama memperhatikan segala sesuatu yang dikemukakan dalam power point.

5) Pujian yang diberikan guru dapat memotivasi siswa untuk lebih baik dalam belajar.

6) Guru sudah berhasil dalam mengarahkan dan membimbing siswa ketika menyimak.

7) Beberapa siswa ada yang mengobrol ketika mengerjakan tugasnya saat menjawab pertanyaan yang berhubungan dengan materi yang telah disimaknya.

8) Guru belum dapat mengelola waktu dengan baik.

Data observasi lainnya menyimpulkan bahwa penggunaan media audio visual dalam bentuk power point dalam pembelajaran Seni Budaya dan Prakarya, pada siklus I sudah berhasil menciptakan suasana dan situasi pembelajaran menjadi lebih menarik sehingga siswa merasa nyaman dan termotivasi dalam menyimak materi yang disampaikan guru melalui media audio visual.

Pembelajaran Seni Budaya dan Prakarya, dengan menggunakan media audio visual dalam bentuk power point ini merupakan pengalaman pertama bagi siswa. Oleh karena itu, siswa merasa antusias dan termotivasi dalam mengikuti pembelajaran tersebut Siswa mengakui media audio viisual dalam bentuk power point sangat membantu mereka untuk mendapatkan inspirasi dalam menyimak materi pembelajaran.

\section{e. Refleksi Siklus I}

Setelah pelaksanaan siklus I selesai, peneliti bersama observer melakukan refleksi terhadap pembelajaran siklus I. Berdasarkan data yang diperoleh dari hasil observasi, catatan lapangan, jurnal siswa, dan hasil tes kemampuan penguasaan materi siswa selama tindakan pembelajaran siklus I, peneliti bersama observer mengadakan diskusi untuk mengetahui hal-hal yang harus dipertahankan, ditingkatkan, atau ditinggalkan. Kegiatan refleksi ini sebagai bahan perbaikan pada tindakan pembelajaran selanjutnya.

Dari identifikasi masalah tersebut dapat disimpulkan bahwa proses tindakan siklus I masih harus ditingkatkan dalam hal keaktifan siswa di kelas. Terbukti selama pembelajaran siklus I dihadapkan dengan permasalahan keadaan kelas yang pasif. Belum banyaknya siswa yang berani untuk menjawab pertanyaan dari guru, mengemukakan pendapat atau pertanyaan, dan berani tampil di depan kelas untuk membacakan jawaban atas pertanyaan yang diberikan. Hal tersebut, diasumsikan karena pertemuan ini adalah pertemuan pertama yang menyebabkan siswa masih terlihat malu dan ragu untuk aktif di kelas. Dalam hal penugasan yang diberikan oleh guru, masih ada siswa yang melakukan kegiatan di luar KBM, seperti mengobrol pada saat proses penyampaian materi dengan menggunakan media audio visual melalui power point dilaksanakan.

Sementara itu penggunaan power point yang sederhana serta kurang memiliki variasi dalam hal tampilannya cenderung menunjukkan kebosanan dari siswa. Dengan demikian tampaknya perlu dilakukan perubahan dan penggunaan media audio 
visual dalam bentuk lain yang lebih menarik bagi siswa.

Adapun hasil pembelajaran siswa yang ditunjukkan dengan kemampuan menjawab pertanyaan yang berhubngan dengan materi yang telah disampaikan selama kegiatan pembelajaran dilaksanakan, secara umum baru mencapai hasil yang cukup baik. Hal ini tampak dari pencapaian rata-rata 6,84. Meskipun sudah mencapai batas ketuntasan yang telah ditentukan yaitu 6,5 , namun apabila diamati dari ketuntasan klasikal atau ketuntasan belajar siswa, masih belum tuntas. Ketuntasan belajar siswa baru mencapai $68,4 \%$, hal ini ditunjukkan dari 32 siswa hanya 23 orang siswa yang sudah mencapai atau melebihi batas ketuntasan yang ditetapkan, sementara 9 orang siswa masih belum mencapai batas ketuntasan yang diharapkan. Dengan demikian secara umum pembelajaran belum tuntas.

\section{Siklus 2}

\section{a. Tahap Perencanaan}

Pada tahap kedua, perencanaan dilakukan sebagai upaya memperbaiki pelaksanaan pembelajaran pada siklus pertama. Ada beberapa hal yang dilakukan dalam upaya melakukan penyempurnaan pada pembelajaran siklus pertama. Beberapa hal yang direncanakan pada siklus kedua antara lain:

1) Mengganti media audio visual yang lebih menarik, yaitu dengan meggunakan $\mathrm{CD}$ interaktif.

2) Mengatur waktu proses pembelajaran dengan lebih menekankan pada proses penggunaan $\mathrm{CD}$ Interaktif serta proses diskusi antar siswa.

3) Memotivasi siswa untuk senantiasa aktif dalam kegiatan pembelajaran.

\section{b. Tahap Pelaksanaan}

Proses pembelajaran pada siklus kedua dilakukan pada tanggal 25 April 2019. Proses pembelajaran diawali dengan mengucapkan salam serta mengabsen siswa, selanjutnya guru memotivasi siswa untuk aktif dalam kegiatan pembelajaran. Upaya membangkitkan motivasi belajar siswa, guru menjanjikan adanya penilaian bagi siswa yang mau menjawab pertanyaan, maupun yang mengajukan pertanyaan serta menanggapi suatu permasalahan. Kemudian guru menyampaikan informasi terkait dengan perilaku konsumtif yang biasa dilakukan siswa dalam kehidupan sehari-hari. Sebagai tindak lanjut hasil temuan jurnal harian siswa pada pembelajaran siklus I, bahwa tingkat motivasi siswa yang masih kurang, guru menggambarkan bahwa belajar Seni Budaya dan Prakarya tidak hanya bersifat teoritis saja, namun seringkali dapat diamati dan dipergunakan dalam kehidupan sehari-hari, di samping itu Seni Budaya dan Prakarya sangat bermanfaat dalam membantu menyelesaikan masalah sehari-hari dan Seni Budaya dan Prakarya berperan penting dalam perkembangan komunikasi sosial di antara sesama.
Menindaklanjuti hasil tes, bahwa masih ada siswa yang salah dalam memberikan pengertian dan pemahamannya terhadap konsep konsumsi serta bagaimana menentukan skala prioritas, guru mengulang kembali pengertian dan konsep konsumsi serta bagaimana langkah-langkah dalam menentukan skala prioritas dalam pemenuhan kebutuhan hidup. Tujuannya adalah agar siswa dapat menumbuhkan kembali pengetahuan dan pengalaman tentang konsep yang telah dipelajari sebelumnya dimana konsep ini diperlukan dalam membahas materi yang akan dipelajari yaitu 'membuat kerajina $\mathrm{n}$ tangan sederhana.

Sebelum melakukan apersepsi untuk materi yang akan disampaikan, terlebih dahulu guru mengulas kembali bagaimana proses pembelajaran dengan menggunakan media audio visual. Guru menjelaskan bahwa pembelajaran yang akan dilaksanakan akan menggunakan media audio visual dalam bentuk CD interaktif.

Tahap selanjutnya, guru menginstruksikan siswa untuk memulai memperhatikan tayangan CD interaktif yang telah disediakan. Guru mencoba menjadi operator pada setiap langkah CD Interaktif tersebut. Pada setiap langkah materi, guru mengajukan pertanyaan kepada siswa apakah materi yang telah ditayangakan dapat siswa pahami atau belum, jika belum guru mencoba mengulanginya kembali. Langkah selanjutnya guru mencoba memandu seluruh materi yang telah disiapkan dalam CD Interaktif tersebut.

Setelah selesai ssiwa memperhatikan CD Interaktif tersebut, seperti biasanya siswa mendiskusikan hasil simakan yang selanjutnya akan dijadikan sebagai bahan pemahaman siswa terhadap materi yang telah disimaknya. Di samping itu, guru menginstruksikan seluruh siswa untuk menuliskan kembali isi materi yang telah disimaknya.

Sebelum pembelajaran berakhir, guru memberikan evaluasi dengan memberikan pertanyaan yang berhubungan dengan materi yang telah disampaikan melalui media CD Interaktif. Setelah diisi, guru menginstruksikan siswa untuk mengumpulkan kembali hasil jawaban siswa. Untuk mematangkan pemahaman ssiwa terhadap materi yang telah disampaikan, guru memberikan pekerjaan rumah kepada siswa untuk dikerjakan di rumah.

\section{c. Hasil Pembelajaran}

Setelah semua hasil pekerjaan siswa dianalisis dengan merujuk pada jawaban yang sebenarnya, dapat disimpulkan bahwa rata-rata siswa telah memiliki kemampuan menjawab pertanyaan dengan baik, meskipun dalam soal-soal yang bersifat pemahaman siswa masih terbatas pada tataran teoretis saja. Hasil penilaian terhadap pekerjaan siswa pada siklus II ini dapat diamati pada tabel berikut ini.

Hasil kemampuan menyimak siswa yang ditunjukkan dengan kemampuan menjawab pertanyaan yang berhubungan dengan materi yang telah diinformasikan yang disimaknya seperti pada tabulasi di atas, tampak bahwa secara umum 
kemampuan siswa dalam menyimak berada pada kondisi yang baik dengan pencapaian rata-rata 69,61 . Nilai tertinggi yang dicapai siswa pada siklus II ini adalah 90 dan nilai terendah yang diperoleh siswa hanya 40. Sementara itu diamati dari ketuntasan belajar siswa pada siklus II ini mencapai ketuntasan belajar sebesar $89,74 \%$. Ketuntasan tersebut menunjukkan bahwa pembelajaran sudah tuntas.

\section{d. Hasil Observasi}

Berdasarkan data observasi, guru telah menyampaikan penjelasan materi dengan jelas dan relevan dengan fokus pembelajaran siklus II. Guru juga sudah berhasil mengarahkan dan membimbing siswa untuk menuangkan hal-hal yang berkesan menurut apa yang dipikrkan dan dirasakan siswa dalam menyimak.

Berdasarkan data observasi terhadap aktivitas siswa dalam pembelajaran diperoleh persentase aktivitas siswa, seperti tampak pada tabel di bawah ini.

Berdasarkan tabel di atas, proses pembelajaran pada siklus II ini terjadi peningkatan yang signifikan dari siklus sebelumnya. Hampir seluruhnya siswa memperhatikan penjelasan guru dan serius dalam mengerjakan tugas. Siswa telah aktif dalam pembelajaran. Dapat dilihatnya dengan banyaknya siswa yang mau tampil di depan kelas, bertanya ataupun mengemukakan pendapat

Hasil catatan lapangan pembelajaran

tindakan kedua dapat dilihat pada tabel di bawah ini.

Tabel 2. Catatan Lapangan Pembelajaran Siklus II

\section{Cat. Lapangan Pembelajaran Siklus II}

1) Siswa antusias untuk mendiskusikan hasil pekerjaan yang telah dikerjakan dengan siswa lainnya di tempatnya masing-masing menjadikan suasana gaduh dalam pembelajaran.

2) Media $\mathrm{Cd}$ Interaktif sebagai media audio visual pembelajaran Seni Budaya dan Prakarya, menjadikan suasana pembelajaran lebih menyegarkan dan menyenangkan.

3) Seluruh siswa serius saat mengerjakan tugasnya untuk menyimak.

4) Sebagian siswa telah berani untuk mengajukan pertanyaan, terutama dalam menanyakan yang berkaitan dengan materi.

Data observasi lainnya menyimpulkan penggunaan media $\mathrm{CD}$ Interaktif dalam pembelajaran Seni Budaya dan Prakarya,sudah berhasil menciptakan suasana dan situasi pembelajaran menjadi lebih menarik sehingga siswa merasa rileks dan termotivasi dalam belajar.

\section{e. Refleksi}

Setelah pelaksanaan siklus II selesai, peneliti bersama observer melakukan refleksi terhadap pembelajaran siklus II. Berdasarkan data yang diperoleh dari hasil observasi, catatan lapangan, dan

\begin{tabular}{l|c}
\hline \multicolumn{1}{c|}{ Aktivitas Siswa } & $\begin{array}{c}\text { Persentase Rata- } \\
\text { rata }(\%)\end{array}$ \\
\hline $\begin{array}{l}\text { 1. Menjawab pertanyaan guru } \\
\text { 2. Mengajukan pendapat atau } \\
\text { bertanya }\end{array}$ & 9 orang $(25,64)$ \\
$\begin{array}{l}\text { 3. Tampil di depan kelas }(23,08) \\
\begin{array}{l}\text { 4. Serius menyimak } \\
\text { penjelasan guru }\end{array}\end{array}$ & 5 orang $(12,82)$ \\
$\begin{array}{l}\text { 5. Serius mengerjakan tugas } \\
\begin{array}{l}\text { 6. Perilaku yang tidak sesuai } \\
\text { dengan KBM }\end{array}\end{array}$ & 37 orang $(94,87)$ \\
\end{tabular}

hasil tes kemampuan pemahaman siswa selama tindakan pembelajaran siklus II, peneliti bersama observer mengadakan diskusi untuk mengetahui halhal yang harus dipertahankan, ditingkatkan, atau ditinggalkan.

Dari diskusi tersebut dapat disimpulkan bahwa proses tindakan siklus II mengalami peningkatan yang signifikan, artinya segi proses tindakan siklus II berhasil. Terbukti bahwa penggunaan media $\mathrm{CD}$ Interaktif sudah mampu memancing motivasi siswa dalam pembelajaran Seni Budaya dan Prakarya,. Siswa merespon positif untuk menjawab pertanyaan dari guru, mengemukakan pendapat atau pertanyaan, berani tampil di depan untuk membacakan hasil jawabannya, dan penugasan dari guru.

Adapun hasil kemampuan hasil belajar siswa yang ditunjukkan dengan kemampuan menjawab pertanyaan yang berhubungan dengan materi yang telah disampaikan melalui media CD Interaktif, secara umum mencapai hasil yang baik. Hal ini tampak dari pencapaian rata-rata 69,61 , yang sudah mencapai batas ketuntasan yang telah ditentukan yaitu 60. Ketuntasan belajar siswa sudah mencapai $89,74 \%$, hal ini ditunjukkan dari 39 siswa, 35 siswa sudah mencapai atau melebihi batas ketntasan yang ditetapkan. Dengan demikian secara umum pembelajaran sudah tuntas.

\subsection{Pembahasan}

Berdasarkan hasil penelitian pada tahap pelaksanaan tindakan, pada umumnya model pembelajaran yang dikembangkan cukup efektif, efisien, dan relevan untuk mengembangkan kemampuan menyimak siswa.

Melihat uraian di atas, dapat diketahui bahwa penelitian yang telah dilakukan cukup efektif, efisien, dan relevan antara komponen-komponen pembelajaran yang dikembangkan, tujuan yang ingin dicapai, dan waktu yang telah direncanakan. Diawali dengan identifikasi permasalahan yang diperoleh 
dari hasil observasi awal, dilanjutkan dengan implementasinya di lapangan beserta hasil refleksinya pada setiap siklus sudah dapat meningkatkan kemampuan siswa dalam pembelajaran Seni Budaya dan Prakarya,.

Perbaikan terhadap model pembelajaran perlu terus dilakukan dalam upaya meningkatkan mutu pendidikan. Beberapa hal yang harus segera dibenahi pada saat penelitian, yaitu pemilihan media audio visual yang lebih menarik sehingga mampu memotivasi siswa dalma belajar.

Agar penggunaan media audio visual sebagai media dan sumber belajar berhasil baik, hendaknya dipersiapkan secara saksama, mulai dari alokasi waktu yang digunakan sampai strategi pelaksanaannya. Persiapan ini bertujuan agar penggunaan media audio visual sebagai media dalam pembelajaran dapat menjadikan siswa merasa fun, santai, dan jauh dari kebosanan, yang pada akhirnya menimbulkan motivasi siswa untuk menyimak sehingga terhindar dari perilaku siswa yang menyimpang dari KBM.

\section{Analisis Data Hasil Penelitian}

Pada bagian ini menganalisis seluruh hasil penelitian selama dua siklus. Adapun pembahasannya mengacu pada data instrumen, meliputi tingkat keberhasilan belajar siswa yang diwujudkan dengan kemampuan menjawab pertanyaan yang berhubungan dengan materi yang telah dipelajarinya.

\section{Tingkat Keberhasilan Siswa Menyimak}

Pembelajaran Seni Budaya dan Prakarya dalam penelitian ini merupakan pengalaman pertama bagi siswa, walaupun demikian pada pertemuan pertama pada umumnya siswa telah dapat memahami materi dengan cukup baik. Pada pertemuan-pertemuan berikutnya, siswa mengalami kemajuan yang cukup signifikan dalam memahami materi yang dipelajarinya.

Untuk mengetahui perkembangan keberhasilan menyimak siswa, diberikan penilaian tiap siklusnya dengan berpatokan pada kriteria penilaian yang telah ditetapkan. Berikut ini merupakan nilai kemampuan menyimak siswa pada tiap siklusnya.

Hasil pembelajaran pada kedua siklus dapat digambarkan pada grafik berikut.

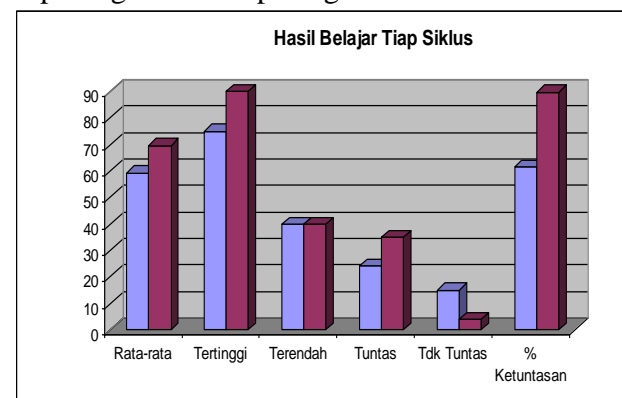

pembelajaran mengalami peningkatan, hanya ada beberapa orang siswa yang kemampuannya tetap namun tidak ada yang menurun. Peningkatan terjadi karena tumbuhnya motivasi dan ketertarikan siswa dalam belajar yang berdampak tumbuhnya keseriusan siswa dalam menyimak materi yang disajikan.

Tingkat pemahaman siswa mengalami peningkatan. Diamati dari pencapaian rata-rata tampak jelas adanya peningkatan dari 59,23 pada siklus I menjadi 69,61 pada siklus kedua. Sementara itu dari pencapaian ketuntasan belajar siswa tampak juga terjadi peningkatan dari $61,54 \%$ pada siklus pertama dan menunjukkan pembelajaran belum tuntas menjadi $89,74 \%$ siswa telah tuntas pada siklus kedua dan menunjukkan pembelajaran telah tuntas.

Terjadinya peningkatan hasil pembelajaran pada pelaksanaan penelitian ini salah staunya disebabkan penggunaan media pembelajaran. Pola pemanfaatan media di luar kelas menurut Arief S. Sadiman (1990:190-197) dapat dibedakan dalam tiga kelompok, yakni kelompok yang terkontrol, tidak terkontrol (bebas), dan jumlah sasarannya.

Pertama, pemanfaatan media secara terkontrol, yakni media itu digunakan dalam suatu rangkaian kegiatan yang diatur secara sistematik untuk mencapai tujuan tertentu, seperti pemanfaatannya di dalam kelas dan pada program pendidikan jarak jauh. Hasil belajar melalui pemanfaatan media secara terkontrol ini biasanya dievaluasi secara teratur dengan alat evaluasi yang terukur.

Kedua, Pemanfaatan media secara bebas (tidak terkontrol), yakni pemanfaatan tanpa ada kontrol atau pengawasan, seperti media-media yang dimanfaatkan masyarakat secara luas dengan cara membeli. Masyarakat itu sendirilah yang menentukan tujuan pemanfaatannya, yakni dengan menyesuaikan dengan kebutuhannya masingmasing, seperti pemanfaatan kaset Seni Budaya dan Prakarya, video interaktif dan lain-lain.

Ketiga, pemanfaatan media dilihat dari jumlah penggunaannya, yakni secara perorangan, kelompok, dan massal. Pemanfaatan media secara perorangan biasanya dilengkapi dengan petunjuk penggunaannya, sehingga pengguna dapat memanfaatkannya secara mandiri, seperti modul. Pemanfaatan media secara kelompok, baik kelompok kecil (2 s.d 8 orang) maupun kelompok besar ( 9 s.d 40 orang). Media untuk kelompok ini biasanya dilengkapi buku petunjuk bagi pemimpin kelompoknya. Setelah atau sebelum memanfaatkan media, kelompok dapat melakukan diskusi. Terakhir, media yang dimanfaatkan secara masal (mulai puluhan, ratusan, hingga ribuan orang). Media untuk massal ini biasanya disalurkan melalui asikus 1
asikus 2 pemancar, seperti radio dan televisi. Sebelum memanfaatkan media ini, peserta diberi bahan tercetak yang memuat tujuan pembelajaran, garis besar isi, petunjuk tindak lanjut, dan bahan dari sumber lain untuk pendalaman pemahaman.

Berdasarkan tabel di atas, pada umumnya nilai kemampuan pemahaman siswa dalam setiap 


\section{SIMPULAN}

1. Proses pelaksanaan pembelajaran IPS dengan menggunakan media audio visual dilakukan dalam dua bentuk media yaitu pada siklus 1 menggunakan power point dan pada siklus 2 menggunakan $\mathrm{CD}$ interaktif. Penggunaan media audio visual ini telah memunculkan beberapa perilaku belajar siswa yang lebih baik. Perilaku tersebut berupa aktivitas siswa yang aktif dalam belajar, seperti siswa yang aktif bertanya, mengemukakan pendapat, dan berani tampil di depan. Siswa juga merasa senang dan berkesan positif dengan pembelajaran yang telah dilaksanakan. Pelaksanaan pembelajaran Seni Budaya dan Prakarya, dengan menggunakan media audio visual sebagai media pembelajaran dilaksanakan melalui langkah-langkah sebagai berikut.

a) Guru terlebih dahulu menjelaskan mengenai tujuan pembelajaran dan strategi pembelajaran yang akan dilakukan.

b) Melakukan apersepsi untuk menghimpun perhatian dan mempersiapkan siswa dalam belajar

c) Siswa memperhatikan penyampaian materi melalui tayangan media audio visual baiak dalam bentuk power point, maupun dalam bentuk CD Interaktif.

d) Siswa mendiskusikan materi yang telah dipelajarinya.

e) Evaluasi

2. Hasil kemampuan pemahaman siswa dalam belajar Seni Budaya dan Prakarya, yang diukur dengan hasil jawaban siswa terhadap pertanyaan yang berhubungan dengan materi yang telah disampaikan dari setiap siklusnya mengalami peningkatan. Hal ini dibuktikan dengan peningkatan rata-rata nilai siswa. Pada siklus I rata-rata siswa mencapai 59,23; pada siklus II mencapai 69,61. ketuntasan belajar siswa juga terjadi peningkatan dari $61,54 \%$ pada siklus 1 meningkat jadi $89,74 \%$ pada siklus ke 2 yang sekaligus menunjukkan bahwa pembelajaran telah tuntas.

DAFTAR PUSTAKA

Al Muchtar, S. (1991). Pengembangan Kemampuan Berpikir dan Nilai dalam Pendidikan IPS. Disertasi. Bandung : PPS IKIP Bandung.

Al Muchtar, S. (2002). "Analisis Pembaharuan Kurikulum Pendidikan IPS". Makalah pada Seminar Nasional dan Musda I HISPISI Jawa Barat, UPI Bandung, 31 Oktober 2002.

Arsyad, Azhar. (2002). Media Pembelajaran. Jakarta: Raja Grafindo Persada.

Association for Educational Communication ant Technology (1977) The Definition of
Educational

Technology.

Washington, DC: AECT.

Awan Mutakin (1998) Model Pembelajaran IPS. Jakarta: P3MTK-Ditjen Dikti

Dahar, Ratna Wilis (2002) Teori-teori Belajar. Jakarta: Erlangga.

Dimyati \& Mudjiono. (1994). Belajar dan Pembelajaran. Jakarta: Rineka Cipta.

Hamalik, O., (1989). Media Pendidikan. Bandung: Alumni.

Nasution (1997). Metode Penelitian NaturalistikOKualitatif. Bandung: Tarsito.

Purwadarminta (1984). Kamus Besar Bahasa Indonesia. Jakarta: Depdikbud.

Rumampuk (1988) Media Instruksional IPS. Jakarta: P2LPTK-Ditjen Dikt

Sadiman (1984) Media Pendidikan; Pengertian, Pengembangan, dan Pemanfaatan. Jakarta: Rajawali Pers

Somantri, (2001), Menggagas Pembaharuan Pendidikan IPS, Rosda, Bandung.

Suryabrata (1984) Psikologi Pendidikan. Jakarta: Rajawali Pers.

Wiriatmadja. (2005). Metode Penelitian Tindakan Kelas untuk Meningkatkan Kinerja Guru dan Dosen. Bandung: PPS UPI dan Remaja Rosdakarya 
